\title{
KILPAILUKYKY, KOULUTUS JA TYÖLLISYYS - EUROOPPALAISIA NÄKÖKULMIA
}

”EU:n työikäisestä väestöstä tulisi peräti 83 prosentin olla työssä, jotta nykyinen väestön huoltosuhde ja sosiaaliturvajärjestelmä voitaisiin säilyttää”, kirjoittaa pääjohtaja Juhani Lönnroth EU:n komissiosta. Euroopassa etsitään yhä tietä kestävään kehitykseen, hyvinvoinnin turvaamiseen ja täystyöllisyyden saavuttamiseen. Kilpailukyky, koulutus ja osaaminen nähdään useimmiten avaimina näiden päämäärien saavuttamiseksi. Mutta jos nämä ovat avaimia parempaan tulevaisuuteen, nousee mieleen joukko kysymyksiä.

\section{PÄÄJOHTAJA JUHANI LÖNNROTH}

- Miksi 40 prosenttia Euroopan aikuisväestöstä ei ole suorittanut keskiasteen koulutusta eräissä EU-maissa jopa 80 prosenttia?

- Miksi vain 8,5 prosenttia aikuisväestöstä EU:ssa keskimäärin osallistuu ammatilliseen aikuiskoulutukseen?

- Miksi vain 16 prosenttia eurooppalaisten yritysten työntekijöistä saa vuosittain yrityksessään jatko- ja täydennyskoulutusta, kun amerikkalaisissa yrityksissä luku on kaksinkertainen, 34 prosenttia?

- Miksi Euroopassa julkiset perus- ja täydennyskoulutuksen menot ovat vain 5 prosenttia BKT:stä, yksityiset menot sitäkin pienemmät, vain 2 prosenttia?

- Miksi niin monet - eräissä maissa jopa 25 prosenttia - keskeyttävät opintonsa Euroopassa ennen kuin ovat suorittaneet lukioasteen koulutuksen?

- Miksi lähes 300 miljoonaa, eli puolet laajentuneen Euroopan Unionin kansalaisista, ymmärtää vain yhtä kieltä - omaansa?

- Miksi kaikissa oppilaitoksissa ei vielä ole internet-yhteyksiä oppilaiden käytössä ja miksi kaikilla opettajilla ei ole tietotaitoa tietotekniikan hyväksikäytössä?

- Miksi yritykset eivät riittävässä määrin anna työntekijöilleen koulutusta tietotekniikan hyödyntämisessä, vaikka yli puolet kaikesta tuotannosta tänään perustuu tiedon tuottamiseen, jakeluun ja hyväksikäyttöön?

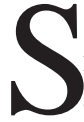

yitä edellä tiivistettyyn tilanteeseen olla monia: koulutusjärjestelmien vajavaisuudet; opetuksen ja työelämän välinen kuilu, koulutuskannustinten riittämättömyys, yrittäjien pelko menettää vaivalla kouluttamansa työntekijä kilpailijan syliin, tai ehkäpä vain päättäjien näköalattomuus keskenään kilpailevien eturyhmien ristiriitaisten menovaatimusten ristitulessa.

Koulutusvajeet ovat kuitenkin ongelma siksi, että sekä työllisyyden että tuotannon kasvu keskittyy yhä enemmän korkeaa koulutusta ja ammattitaitoa vaativille aloille. Osaaminen ja tietoyhteiskunta toimii rakennemuutoksen veturina. Lisäksi koulutus ruokkii itseään: korkeammin koulutetut osallistuvat muita useammin jatko- ja täydennyskoulutukseen - koulutus siis imee mukaansa. Tiedämme myös, että vähemmän koulutettujen työttömyys- ja syrjäytymisriskit ovat 
muita huomattavasti suuremmat. Lisäksi yhteiskunnan kahtiajakautumiselle on tullut uusi uhkatekijä: digitaalinen kuilu. On niitä jotka osaavat, ja niitä, jotka eivät osaa. On niitä joilla on ja niitä joilla ei ole. On niitä jotka pääsevät yhteiskunnan ytimeen ja niitä, jotka syrjäytyvät.

EU:n kymmenessä uudessa jäsenmaassa haasteet ovat vielä suuremmat: Vaikka pinnalta katsoen näyttäisikin siltä, että keskiasteen koulutuksen saavuttaneiden määrä ei juurikaan poikkeaisi entisen EU:n 15 jäsenmaan kansalaisista, on korkea-asteen koulutuksen saaneiden määrä jo ratkaisevasti pienempi. Lisäksi ovat julkiset - ja etenkin yksityiset - koulutusmenot monissa uusissa jäsenmaissa merkittävästi pienemmät: Yritykset eivät ole kiinnostuneita kouluttamaan omaa työvoimaansa. Koulutuserot maaseudun ja kaupunkien välillä ovat huomattavat. Koulutuksen sisältö painottuu myös usein perinteisiin aloihin ja ammatteihin. Uusien jäsenmaiden työmarkkinoiden rakenteesta johtuu lisäksi se, että niissä heikosti koulutettujen työttömyys-, syrjäytymisriski on paljon suurempi kuin ”vanhassa” EU:ssa.

\section{Lissabonin strategia:}

\section{KOHTI KESTÄVÄÄ KASVUA, TÄYSTYÖLLISYYTTÄ JA SOSIAALISTA YHTENÄISYYTTÄ}

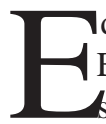
1 dellä esittämäni kysymykset johtavat koko EU:n talous- ja sosiaalipoliittisen tulevaiIsuuskeskustelun ytimeen. Euroopan Unionihan hyväksyi Lissabonin huippukokouksessa maaliskuussa vuonna 2000 kunnianhimoisen strategian, jonka perimmäisenä tavoitteena on "tehdä EU:sta vuoteen 2010 mennessä maailman kilpailukykyisin, innovaatioon ja osaamiseen perustuva kansantalous, joka kykenee ylläpitämään kestävää taloudellista kasvua, korkeaa työllisyyttä ja sosiaalista yhteenkuuluvuutta”.

Tänä päivänä, neljä ja puoli vuotta myöhemmin, Lissabonin strategia kuulostaa kovin mahtipontiselta. Yhä useammat ovat kysyneet, onko noiden kunnianhimoisten tavoitteiden saavuttaminen edes mahdollista tämänhetkisen kansainvälisen ilmapiirin taustaa vasten, jota leimaavat jatkuvan terrorismin uhan, Irakin sodan jälkimaininkien ja öljyn hinnannousun sekä kansainvälisen politiikan ristiriitojen mukanaan tuoma epävarmuus ja talouskasvun heiveröisyys. Euroopan Komissio joutuikin seurantaraportissaan ke- vään 2004 huippukokoukseen toteamaan, että strategian tavoitteita ei tulla saavuttamaan vuoteen 2010 mennessä, mikäli nykyinen meno Euroopassa jatkuu.

Tämä ei kuitenkaan merkitse sitä, että Lissabonin strategiasta sinänsä olisi luovuttava. Pikemminkin päinvastoin. Näin ovat myös Euroopan unionin päättäjät todenneet. Lissabonin strategiassa on näet kaksi uutta piirrettä, jotka ovat relevantteja aikajänteestä riippumatta ja joita ei EU:n yhteiskuntapoliittisessa ajattelussa ennen juuri ollut:

- Näistä ensimmäinen on strategian kokonaisvaltaisuus: EU:n sisämarkkinoiden kasvupolitiikan, työllisyyspolitiikan ja sosiaalisen hyvinvointipolitiikan kehittämisen on oltava tasapainoista, toisiaan tukevaa. Ilman tätä tasasivuista "Lissabonin kolmiota” tasapainoinen yhteiskuntakehitys sekä myös EU:n legitimiteetti, uskottavuus kansalaisten silmissä vaarantuvat. Vuoden 2002 jälkeen voimme itse asiassa puhua "Lissabonin kaksoiskolmiosta”, koska strategiaan Göteborgin huippukokouksessa lisättiin kestävän kehityksen ulottuvuus.

- Toinen uusi ominaispiirre on EU:n kehitystyön tulostavoitehakuisuus, näkemys, ettei ilman täsmällisiä, usein numerollisia tulostavoitteita päästä eteenpäin. Mitä mitataan, sitä myös tehdään. Siksipä Lissabonin kolmion kaikilla osaalueilla on asetettu määrällisiä tavoitteita, joita seurataan yhteisesti hyväksyttyjen indikaattorien avulla. Tavoitteisiin kuuluvat koko työikäisen väestön työllisyysasteen nostaminen nykypäivän 64 prosentista 70 prosentin tasolle, naisten osalta 55:stä 60:een ja yli 55-vuotiaiden osalta nykyisestä 39 prosentista 50:een. EU:n tulisi myös lisätä tutkimus- ja kehitysmenojen osuutta BKT:stä Yhdysvaltain tasolle 3 prosenttiin sekä puolittaa köyhyysuhan alaisen väestön määrä.

Lissabonin strategia on kiistämättä jäntevöittänyt EU:n yhteiskuntapoliittista keskustelua sekä yhtenäistänyt ja uudelleensuunnannut EU:n toimenpiteitä. Monet, aiemmin erillisinä toteutetut EU-tason "prosessit” kuten vuonna 1997 käynnistetty Euroopan työllisyysstrategia nähdään nyttemmin Lissabonin strategian kiinteänä osaalueena. Lisäksi mm. talous- ja työllisyyspolitiikan alueella laadittavia suosituksia ja suuntaviivoja on keskenään yhteen sovitettu sekä ajallisesti että sisällöllisesti. Lisäksi Lissabonin strategia näkyy rakennerahastojen tavoitteistossa ja toimeenpanossa. Se on myös vaikuttanut Komis- 
sion keväällä 2004 tekemään ehdotukseen EU:n tulevista rahoituskehyksistä, sekä rakenteen että sisällön osalta.

Mutta Euroopan Komissio on myös osoittanut sormella jäsenmaiden hallituksia hitaudesta sekä siitä, etteivät ne ole määrätietoisesti tarttuneet välttämättömiin uudistuksiin, jotka on yhteisesti hyväksytty. Ministerineuvostot sorvaavat mieluusti julkilausumia, mutta kansalliset realiteetit tekevät usein toimeenpanosta vaikean. "Eurooppaa” ei aina nähdäkään veturina vaan syntipukkina kansallisiin vaikeuksiin.

Komissiossa ja ministerineuvostoissa myös työmarkkinajärjestöt ovat usein enemmän tai vähemmän peitellyn kritiikin kohteina. Järjestöjen katsotaan mieluusti neuvottelevan sellaisista yksityiskohdista, joista odotetaan voitavan päästä sopimukseen. pikemmin kuin kokonaisvaltaisen strategian pohjalta. Vaikeat, yhteiskuntapoliittisia valintoja edellyttävät asiat haudataan ns. työryhmiin.

Toisaalta on kiistatonta, että Lissabonin kolminapainen strategia ei ole haudannut sen rakenneosien taustalla olevien yhteiskuntapoliittisten valintojen ideologisia painotuseroja. Nyt näyttää markkinavetoinen kilpailukyky olevan niskan päällä talouskasvun vauhdittamisessa tasa-arvonäkökohtia korostavaan sosiaaliseen tulonsiirtopolitiikkaan ja rakennetukipolitiikkaan verrattuna. Tämän on sanottu näkyvän myös Barroson uuden komission ensimmäisissä valinnoissa. Näiden väitteiden todellisuuspohja todentuu kuitenkin vasta tulosten ollessa näkyvillä.

\section{EUROOPAN SOSIAALIMALLI ON YKSIN KESTÄMÄTÖN}

Euroopassa, ja erityisesti pohjoismaissa olemme valinneet yhteiskuntamallin, jossa hyvinvointi rahoitetaan verotuloilla ja turvataan tulonsiirroilla, jotka puolestaan perustuvat palkkatyöhön. Ns. "työlinja”, työn ensisijaisuus toimeentulon ja hyvinvoinnin lähteenä on siis ns. "eurooppalaisen sosiaalimallin” perusta. Tämän hyvinvoinnin ylläpitäminen ja edelleen kehittäminen rakentuu siksi kestävän talouskasvun ja korkean työllisyyden turvaamisen varaan. Mutta se edellyttää myös, että kansantalouden kilpailukyky ja sopeutuminen jatkuvaan rakennemuutokseen voidaan varmistaa.

Kestävän kasvun uralle pääsemiselle ja hyvinvointimme jatkuvalle turvaamiselle on kuitenkin

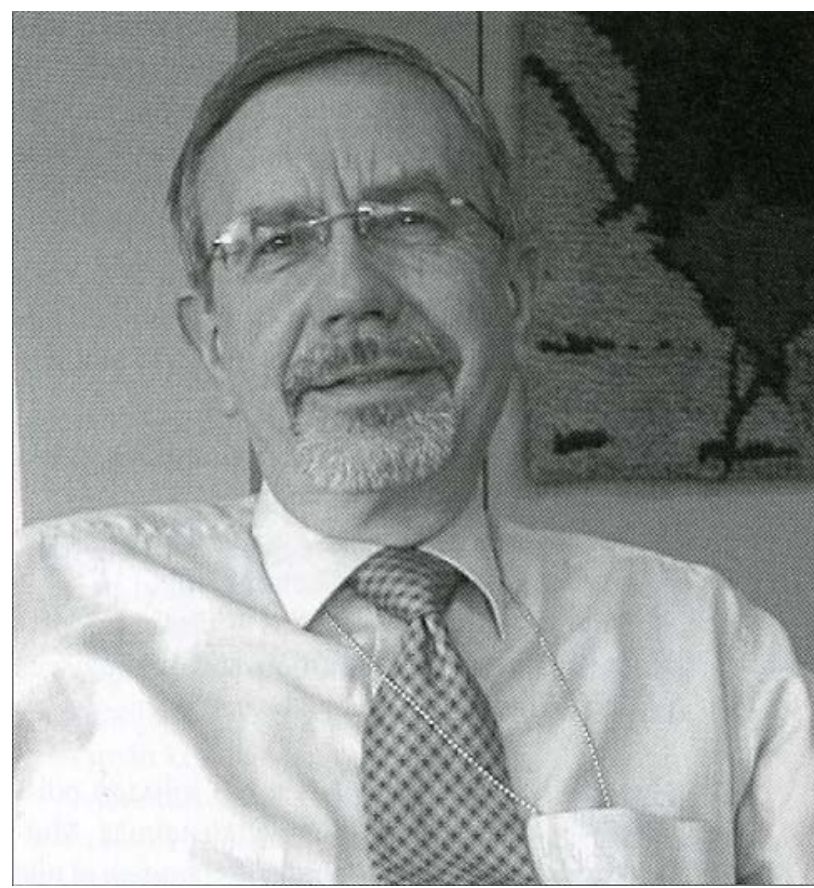

Johtaja Juhani Lönnroth, EU:n komissio

useita reunaehtoja. Näistä mielestäni kuitenkin kaksi nousee ylitse muiden:

1. Meidän on turvattava työvoiman saatavuus; ja

2. Meidän on investoitava elinaikaiseen oppimi seen.

Mitä tulee työvoiman tarjontaan, tiedämme, että - Vaikka nettosiirtolaisuus EU:n ulkopuolelta jatkuisikin nykytasollaan, eli noin miljoona maahanmuuttajaa vuodessa, alkaa koko EU:n väkiluku laskea vuonna 2023. Maat ovat tässä hieman eri kehitysvaiheessa, mutta Suomessa väki alkaa vähetä suurin piirtein samoihin aikoihin kuin EU:ssa keskimäärin. Vuonna 2050 on EU:ssa kaikkiaan jo 40 miljoonaa ihmistä vähemmän kuin nyt. Työikäisen väestön määrä alkaa laskea vielä paljon aiemmin - jo 2010-luvulla.

- Samanaikaisesti väestön ikärakenne vanhenee nopeasti: seuraavien viidentoista vuoden aikana yli 80-vuotiaiden määrä kasvaa 50 prosenttia, alle 25-vuotiaiden määrä vähenee seitsemän prosenttia. Seurauksena väestön huoltosuhde muuttuu rajusti. Tänä päivänä meillä on yhtä huollettavaa kohti neljä työllistä, yhden sukupolven kuluttua niitä on enää kaksi. Vaikutukset terveydenhoitomenoihin, eläkekustannuksiin ja huoltohenkilökunnan kysyntään ovat dramaattiset, ellei mitään tehdä. 
- Useissa maissa ja etenkin julkisella sektorilla puolet palveluhenkilöstöstä jää lähimmän 5-10 vuoden kuluttua eläkkeelle. Ja tämä juuri sellaisissa mm. hoitoalan ammateissa, joissa paineet ja henkilöstön tarve kasvavat.

Kun siis työvoiman saatavuuden tulevaisuus näyttää tällaiselta, mitä tulisi tehdä, jos mieli turvata eurooppalainen hyvinvointimalli? Vaihtoehtoja on vain kolme:

1. Työllisyysasteiden edelleen nostaminen luomalla "työtä kaikille";

2. Tuottavuuden voimakas kasvattaminen aikaansaamalla "enemmän vähemmällä”;

3. Maahanmuuton voimakas lisääminen lopettamalla puhuminen Euroopasta jonkinlaisena "lintukotona" tai "linnakkeena".

Nuo kolme vaihtoehtoa eivät ole toisiaan poissulkevia. Tarvitsemme niiden yhdistelmää. Mutta helppoa oikean yhdistelmän löytäminen ei tule olemaan.

\section{TYÖLLISYYSASTEEMME ON LIIAN MATALA}

EU:n työikäisestä väestöstä tulisi peräti 83 prosentin olla työssä (verrattuna nykypäivän 64 prosenttiin), jotta nykyinen väestön huoltosuhde ja sosiaaliturvajärjestelmä voitaisiin säilyttää. Ja jotta yltäisimme edes Lissabonin strategian edellyttämään 70 prosentin työllisyysasteeseen, meidän tulisi luoda 22 miljoonaa uutta työpaikkaa laajennetussa, 25 jäsenmaan EU:ssa! Näistä peräti 10 miljoonaa tulisi osoittaa yli 55-vuotiaille.

Kaikissa pohjoismaissa työllisyysasteet ovat jo verraten korkeat. Kovin paljon työvoimareserviä ei siis löydy. Kuitenkin näissäkin maissa on yksilöitä ja ryhmiä, joiden kilpailuasema työmarkkinoilla on heikko tai joiden syrjäytymisriski on suuri. Heitä on siirtolaisväestössä, etnisissä vähemmistöissä, vajaakuntoisissa, yksinhuoltajissa, heikosti koulutetuissa. Ja heitä on etenkin juuri edellä mainituissa yli 55-vuotiaissa, joita kolmenkymmenen vuoden aikana on työmarkkinajärjestöjen yhteisin ponnistuksin niin suurissa kuin pienissäkin kriiseissä lakaistu ulos työmarkkinoilta, ”koska valtio tai eläkekassa maksaa”, ja koska ”nuoriakin olisi tulossa”. Asenteet ovat vähän samat kuin ympäristön saastuttajilla: ”meidän jälkeemme vedenpaisumus". Nuorten ja vanhempien ikäluokkien vastakkain asettelussa Kalevalan viisaudet on otettu turhan kirjaimellisesti:

"Kas siitäpä nyt tie menevi, ura uusi urkenevi, laajemmille laulajille, runsahammille runoille, nuorisossa nousevassa, kansassa kasuavassa..."

Runot eivät toki auta työvoimareservien saamiseksi työmarkkinoille ja siellä pysymään. Tarvitaan työpaikkoja, eikä vain niitä. Tarvitaan määrätietoista ja kattavaa politiikkaa, joka ulottuu asennemuutoksesta ja eläkeratkaisuista houkutinjärjestelmiin, joilla saadaan ihmiset haluavat rekrytoimaan ja etsimään työtä,. Tarvitaan liikennepalvelujen päivähoitopalvelujen ja työorganisaatioiden, työterveyshuollon sekä työolojen edelleen kehittämistä.

\section{HÄVIÄMME AMERIKKALAISILLE TYÖN TUOTTAVUUDESSA}

Mitä tulee työn tuottavuuteen kilpailukyvyn ja työvoiman riittävyyden turvaamiseksi, joudumme toteamaan, että työtuntia kohti mitattu tuottavuus on EU:ssa noin viisi prosenttiyksikköä alhaisempi kuin Yhdysvalloissa. Jos vertaamme tuottavuutta henkilöä kohti, olemme peräti 17 prosenttiyksikköä Yhdysvaltoja jäljessä. Tämä kuilu näyttää lisäksi kasvavan. Syyt ovat ilmeiset: Me eurooppalaiset yksinkertaisesti teemme vähemmän työtä. Meillä on lyhyemmät työajat ja työllisyysaste on 10 prosenttiyksikköä alhaisempi.

Myös näiltä osin tarvitaan tietoisia työelämän uudistuksia, työaikareformeja, työn uudelleenorganisointia, työpaikkojen laadun parantamista, työsuojelun tehostamista ja esimerkiksi sairauspoissaolojen vähentämistä, jotka Suomessa ovat eurooppalaista huipputasoa.

EU:n kymmenessä uudessa jäsenmaassa tuottavuus on monasti vain murto-osa vanhojen EUmaiden tuottavuudesta. Tämä ei koske vain maataloutta, vaan myös useita teollisuusaloja. Tuottavuus toisaalta kasvaa nopeasti, mikä merkitsee nopeaa ja usein kivuliasta työvoiman uusjakoa. Esimerkiksi Puolan terästeollisuus työllisti vuosikymmen sitten 120000 henkilöä. Vuosina 19922002 tuottavuus kasvoi kolminkertaiseksi, mutta työvoima väheni neljänteen osaan, 30000 henkilöön. Eikä rakennemuutosten kourissa kamppaileva työvoima omaa niitä tietotaitoja, joita myöhäisteollinen yhteiskunta kaipaa. Tarvitaan siis massiivista uudelleen- ja täydennyskoulutusta, jotta rakennemuutos veisi kohti työttömyyden vähenemistä ja parempaa työllisyyttä. 
MAAHANMUUTTO JA TYÖ-

VOIMAN LIIKKUVUUS EIVÄT VAIKUTA RIITTÄVÄSTI

Alueellinen muuttoliike on Euroopassa sangen vähäistä, vain noin kolmannes Yhdysvaltain vastaavasta. Siksipä moni toivoisi, että maahanmuuton lisääminen voisi ratkaista työvoiman saatavuusongelmat Euroopassa. Tämä ei ole kuitenkaan aivan yksinkertaista:

- Maahanmuuttajat omaksuvat hyvin nopeasti uuden emämaansa väestön lisääntymiskulttuurin. Syntyvyys siksi tuskin lisääntyy pitkällä aikavälillä merkittävästi, eikä väestön ikärakenne pitkällä aikavälillä juurikaan parane.

- EU:n uusien jäsenmaiden ikärakenne ei juurikaan poikkea EU:n vanhojen jäsenmaiden vastaavista, ja syntyvyysluvut ovat alhaiset. Ne tulevat siis kohtaamaan samat väestörakenteen ja työvoiman tarjonnan ongelmat kuin mekin.

- Koska kaikki EU-maat ovat samassa veneessä työvoiman saatavuutensa suhteen, tulee kilpailu ulkoa tulevasta työvoimasta olemaan varsin kovaa. Kilpailussa voittaa se, joka voi tarjota parhaat työolot, parhaat integraatiomahdollisuudet, parhaat urakehitysedellytykset.

- Vaikka uusista EU:n jäsenmaista peräisin olevien kansalaisten määrän EU:n vanhoissa jäsenmaissa arvioidaankin kasvavan kolmessakymmenessä vuodessa tämänhetkisestä noin miljoonasta kansalaisesta noin neljään miljoonaan (ja suurin osa näistä tulisi oletettavasti asumaan Saksassa ja Itävallassa), olisi se sittenkin vain noin prosentin verran EU:n vanhojen jäsenmaiden koko väestöstä. Siten sekä pelot että toiveet uusista jäsenmaista tulevista mahtavista siirtolaisvirroista ovat vahvasti ylimitoitettuja. EU:n on siis hallittava rakennemuutos, kilpailukykynsä jatkuva kehittäminen ja yhteiskuntamallinsa säilyttäminen pääosin olemassa olevalla työvoimallaan, ottaen huomioon tulevat väestönmuutokset. Tämä asiaintila on myös Komission peruslähtökohta sen pyrkiessä edistämään mm. EU:n jäsenmaiden siirtolaispolitiikan parempaa koordinointia ja maahanmuuttajaväestön tehokkaampaa integrointia työelämään sekä ns. ”Aktiivista ikääntymistä”. Viimeksi mainitussa perusajatuksena ei ole vain toimenpiteiden kohdentaminen vanhimpiin, yli 55-vuotiaisiin, vaan kokonaisvaltainen "elämänkiertoajattelu”, jossa tavoitteena on työhalun ja työkyvyn ylläpitäminen yksilön koko elämänuran aikana.

\section{ELINAIKAINEN OPPIMINEN ON HYVINVOINTIMME PERUSTA}

Elinaikainen oppiminen on kaikkien edellä mainittujen aloitteiden keskiössä. Se on nähtävä avaimena sosiaaliseen osallistumiseen, työllisyyteen, sekä yrityksen että yksilön kilpailukykyyn ja sopeutumiskykyyn. Elinaikainen oppiminen ei saa olla vain hallitusten toiminta- ja tavoitekentässä. Se koskee yhtä lailla työnantajia, palkansaajajärjestöjä, kansalaisyhteiskuntaa kuin paikallisia ja alueellisia toimijoita.

EU on asettanut useita määrällisiä tavoitteita osaamisyhteiskunnan kehittämiseksi. Erityisesti uusissa työllisyyspolitiikan suuntaviivoissa edellytetään, että

- vuoteen 2010 mennessä tulisi vähintään 85 prosentilla 22-vuotiaiden nuorten ikäluokasta olla ylemmän keskiasteen tutkinto;

- vähintään 12,5 prosenttia työikäisestä väestöstä tulisi osallistua elinaikaiseen oppimiseen;

- koulunsa keskeyttäneiden osuus Euroopassa keskimäärin puolittuisi 10 prosenttiin vuonna 2010.

Sen lisäksi EU:ssa halutaan jäsenmaiden lisäävän investointeja inhimilliseen pääomaan, avaavan Internet-yhteydet kaikkiin kouluihin ja kaikille oppilaille, lisäämään opettajien tietotaitoja tietotekniikan hyväksikäytössä ja nostamaan myös työvoiman tietoteknistä osaamista.

\section{SUOMI MUKANA OSAAMISEN JA AKTIIVISEN IKÄÄNTYMISEN HERÄTYSLIIKKEESSÄ}

Euroopan Komissio ja muut eurooppalaiset toimijat, mukaan lukien työmarkkinajärjestöt, ovat viime vuosina käynnistelleet Euroopan laajuista "herätysliikettä” niin elinaikaisen oppimisen kuin ”aktiivisen ikääntymisenkin” edistämiseksi. Pohjoismaat, Suomi mukaan luettuna, ovat olleet hyvin mukana molemmissa. Suomessa laaja-alainen kansansivistystyö, kansakoululaitoksineen ja kyläkirjastoineen on 1800-luvulta asti myötävaikuttanut suomalaisen yhteiskunnan kehittymiseen siksi hyvinvointiyhteiskunnaksi ja sivistysvaltioksi, sekä informaatioteknologian kärkimaaksi, mitä Suomi tänään on. Ja mitä tulee ”aktiiviseen ikääntymiseen” Suomi on niitä harvoja EU maita, jotka voivat ylpeillä muutaman vuoden takaisella kokonaisvaltaisella "kansallisella ikäohjelmalla”, joka jatkotoimenpiteineen on sekä nos- 
tanut yli 55-vuotiaiden työllisyysastetta että myöhentänyt tosiasiallista eläkkeellesiirtymisikää.

Myös seurantatilastot puhuvat Suomen ja muiden Pohjoismaiden saavutuksista selvää kieltään. Kun puhutaan investoinneista inhimilliseen pääomaan, osallistumisesta aikuiskoulutukseen, keski- tai ylemmän asteen tutkinnon suorittaneista, panostuksesta tutkimukseen, kehitykseen tai informaatioteknologiaan, Suomi kuuluu Euroopan kärkimaihin. Suomen ja muiden Pohjoismaiden katsotaan yltäneen Lissabonin strategian toimeenpanossa yleisemminkin parempiin tuloksiin kuin muut jäsenmaa, koska ne ovat samanaikaisesti usealla rintamalla ja kokonaisvaltaisesti pyrkineet toteuttamaan kaikkia Lissabonin strategian osa-alueita.

Mutta tämä ei merkitse sitä, että suomalainen yhteiskunta ilman jatkuvia ponnistuksia myös säilyy kärjessä tulevaisuudessa. Suomalaiset pärjäävät erinomaisesti kansainvälisissä luku- ja laskutaitovertailuissa. OECD:n ns. Pisa-tutkimus on tästä oiva esimerkki. Muiden maiden päättäjät katsovat kademielellä, miten se on mahdollista. Kysyä kuitenkin sopii, kannattaako meidän niin kauheasti röyhistää rintaamme siitä, että osaamme muita paremmin lukea ja kirjoittaa Suomen kielellä, jos kukaan muu maailmassa ei ymmärrä sitä, mitä luemme ja kirjoitamme... Ja lisäksi, suomalaisten peruskoulujen vuosittainen tuntimäärä näyttää olevan Euroopan alhaisimpia...

Elämme uudessa Euroopassa, uudessa maailmassa. Sen haasteet ovat jatkuvassa liikkeessä, vaatimukset kasvavat, ja taivaanranta etääntyy sitä mukaa kun kiiruhdamme eteenpäin. Meidän tulee jatkossa entistä taitavammin kytkeä huoltovaltion turvallisuus työmarkkinoiden joustavuuden vaatimuksiin. Meidän tulee voida löytää tasapaino vastuun, omatoimisuuden, aktiivisuuden sekä houkuttimien ja toisaalta sen turvallisuuden välille, jonka verovaroin rahoitetut turvaverkot meille antavat. Meidän tulee kehittää "työlinjaa” - työn tarjonnan ja kysynnän ensisijaisuutta: Työn tulee kannattaa, mutta sen tulee myös olla houkuttelevaa, laadukasta ja kehittävää, sen tulee olla turvallista ja antaa uralla etenemisen mahdollisuuksia.

Euroopassa vaaditaan suuria ponnistuksia, jotta voisimme vastata niihin kahteen perushaasteeseen, joita olen edellä hahmottanut: väestökehityksen ja osaamisen ongelmiin. Nämä ovat kuin siamilaiset kaksoset - vahvasti toisiinsa sidok- sissa. Tarvitsemme Euroopassa yksinkertaisesti lisää väkeä töihin, tarvitsemme entistä osaavampia yksilöitä, naisia ja miehiä, jotka voivat hallita muutosta ja sopeutua siihen. Tarvitsemme siksi myös väkeä, joka pyrkii jatkuvasti tiedon lähteille peruskoulusta eläkeikään. Tämä edellyttää puolestaan nykyistä joustavampaa, laadullisesti korkeatasoisempaa, ajantasaisempaa ja houkuttelevampaa koulutustarjontaa.

Kenen on siis vastuu? Hallitusten ja muiden poliittisten päättäjien on toki luotava lainsäädännölliset, verotukselliset ja hallinnolliset puitteet ja toimintaedellytykset. Mutta myös yrityksillä ja yksilöillä itselläänkin on keskeinen rooli ja vastuu aktiivisen ikääntymisen ja elinaikaisen oppimisen strategiassa.

\section{YRITYKSILLÄ PÄÄVASTUU OMAN TYÖVOIMANSA KEHITTÄMISESTÄ}

Mitä tulee yrityksiin, on toki niiden oman edun mukaista tulevan väestökehityksen valossa huolehtia omasta työvoimastaan. Tämä vaatii kuitenkin usein kahdenlaista asennemuutosta:

- Vanhempien työntekijöiden tuottavuus tuskin on heikompaa kuin nuorempien. Vanha fysiikan laki "mikä voimassa voitetaan se matkassa menetetään” on luettava toisin päin: Se mikä ehkä puuttuu fyysisessä voimassa ja nuoruuden innossa korvautuu kokemuksella, harkinnalla ja ongelmien ratkaisukyvyllä. Sitä paitsi esim. saksalaiset tutkimukset osoittavat, ettei vanhempien omaksumiskyky ja koulutushalukkuus välttämättä ole heikompaa kuin nuorten.

- Koulutusta ja työssä oppimista ei tule nähdä kulutusmenona vaan investointina. Siksi ne yritykset jotka panostavat jatkokoulutukseen ja hyvään henkilöstöpolitiikkaan ovat useimmiten menestyvämpiä kuin muut. Yritykset tulisi siten nähdä myös oppivina organisaatioina eikä ainoastaan tuotantokoneistona. Tämä on myös osa sitä yritysten yhteiskuntavastuuta, josta me niin kauniisti EU:ssa puhumme.

\section{KOULUTUSPOLITIIKALLE HAASTEITA}

Mutta myös politiikan suuntaamisessa on omat ongelmansa, joihin tulee määrätietoisesti tarttua:

1. Miten voimme saada aikaan koulutusinvestointien kasvua, kun talouskasvu hiipuu, paineet 
tulo- ja menoarvioiden vakauttamiseksi kasvavat ja väestökehityksen vaikutukset muiden julkisten menojen, kuten sosiaaliturvan ja eläkkeiden kasvuun ahdistavat?

2. Miten muuttaa julkisten menojen rakennetta osaamisen ja tietotaidon nostamisen hyväksi asettamalla muissa menoryhmissä ns. negatiivisia prioriteetteja, kun tiedämme että yhteiskuntapolitiikan tavoitteet ja tarpeet ovat usein toisilleen ristikkäisiä ja riippuvat paljolti myös erilaisten eturyhmien keskinäisistä voimasuhteista?

3. Miten voimme parantaa opetuksen ja koulutuksen laatua ja tehokkuutta parantamalla seurantamenetelmiä ja indikaattoreita ja madaltamalla muodollisen ja "epämuodollisen” koulutuksen raja-aitoja?

4. Miten voimme kehittää parempaa ja tehokkaampaa kumppanuutta yksityisen ja julkisen sektorin kesken, ei ainoastaan rahoituksen suhteen vaan kytkemällä työelämä, akateeminen maailma, yritykset ja muut toimijat paremmin yhteen saavuttaaksemme laadullisesti paremman tuloksen ja koulutuksen laajemman kattavuuden?

5. Miten voi Euroopan Unioni myötävaikuttaa paremmin ja tehokkaammin inhimillisten voimavarojen kehittämiseen. Koulutusvajeet, digitaalinen kuilu, syrjäytyminen ja kilpailukyvyn puute eivät ole vain ns. Kehitysalueiden (tai ns. 1-alueiden) ongelma. Ne ovat, kuten edellä olemme nähneet, koko EU:n alueen kattavia haasteita ja ilmenevät niin maiden kuin alueiden välilläkin, aina pienimpään paikallisyhteisöön asti. Eikö siis olisi ratkaisevan tärkeää asettaa inhimillisten voimavarojen kehittäminen paraikaa uusittavana olevan EU:n rakennerahastopolitiikan keskiöön? Tiet, sillat ja perusrakenneinvestoinnit ovat tärkeitä. Mutta jos teiden päässä ei ole ihmisille elantoa, työtä ja kehitysmahdollisuuksia, niin tiet johtavat kylistä poispäin ja susirajan takainen maa autioituu.

6. Ja lopuksi, minkälaisia houkuttimia tulisi yhteiskuntapolitiikan tarjota yksittäiselle kansalaiselle ja yrittäjälle jotta he haluaisivat osallistua ja tarjota koulutusta? Ja mitä menestymisen mahdollisuuksia näillä houkuttimilla on, ellei niitä kytketä aktiiviseen työllisyyspolitiikkaan, joka luo koulutuksen jälkeisiä työn ja toimeentulon mahdollisuuksia?

Nämä haasteet ovat osa sitä integroitua strategiaa, sitä yhteiskuntavastuuta, jonka on oltava olemassa, jotta Lissabonin kolmion tavoitteet voisivat toteutua. Tuo politiikan kokonaisuus voidaan parhaiten tiivistää tuhatvuotiseen kiinalaiseen viisauteen:

”Jos suunnittelet vuodeksi, kylvä vehnää. Jos suunnittelet kymmeneksi vuodeksi, istuta puita. Jos suunnittelet elinajaksi, kouluta ihmisiä.”

Juhani Lönnroth on vuoden 2004 alusta toiminut Euroopan Komission Käännöstoimen pääosaston pääjohtajana. Hän toimi aiemmin Euroopan Komission Työllisyys- ja sosiaaliasiain pääosaston varapääjohtajana, vastuualueenaan Euroopan työllisyysstrategia ja Euroopan Sosiaalirahasto. 